\title{
OPN -443C > T Genetic Polymorphism and Tumor OPN Expression are Associated with the Risk and Clinical Features of Papillary Thyroid Cancer in a Chinese Cohort
}

\author{
Guoyu Mu ${ }^{a}$ Hongjiang Wang ${ }^{a}$ Zhengang Cai ${ }^{a}$ Hong Jib
}

aBreast surgery department, the First Affiliated Hospital of Dalian Medical University, 11601, Dalian City, Liaoning Province, China; ${ }^{b}$ Gynecology and obstetrics department, the second Affiliated Hospital of Dalian Medical University, 116023, Dalian City, Liaoning Province, China

\section{Key Words}

Papillary thyroid cancer • Osteopontin • Polymorphism • Risk

\begin{abstract}
Aim: to test the possible association between the polymorphism of Osteopontin (OPN) gene with the risk and the clinical features of papillary thyroid cancer (PTC). Methods: A total of 363 PTC patients and 413 healthy controls were enrolled. OPN expressions in tumor tissue were detected by immunohistochemistry. OPN gene polymorphisms, namely, $-66 \mathrm{~T}>\mathrm{G}$ ( $\mathrm{rs} 28357094)$, -156G > GG (rs17524488), and -443C>T (rs11730582), were determined. Results: We observed that the PTC patients had significantly higher rates of $-443 T$ T genotypes than controls $(P<0.001)$. The multivariate logistic regression analysis showed a significantly increased risk for PTC for the $-443 C \mathrm{C}$ genotype compared with the $-443 \mathrm{TT}$ genotype (adjusted OR=4.312, 95\%CI: 2.747 -6.987, adjusted $\mathrm{P}<0.001$ ). OPN protein was not expressed in normal thyroid tissues while tumor samples from PTC patients were shown to have high expressions of OPN. Also, we found that the high OPN expressions were significantly more prevalent in -443CC carriers than TT carriers $(P<0.001)$. Both the CC carriers and OPN expression were closely associated with the cervical lymph node metastasis and angiolymphatic invasion of PTC. Conclusion: This study provides evidence to support the connection between the OPN genetic polymorphism and tissue expression with risk as well as the invasiveness of PTC.
\end{abstract}

Copyright $(2013$ S. Karger AG, Basel

\section{Introduction}

Thyroid tumors are the most common malignancies of the endocrine system. They account for roughly $1 \%$ of all new malignant diseases and are the sixth most common malignancy diagnosed between the ages of 20 and 49 years [1,2]. Papillary thyroid cancer 
(PTC) account for the majority of thyroid tumors [3]. Radiation exposure is the strongest known risk factor for PTC [4]. However, examining other risk factors, such as genetic factors, could help to advance in the treatment and prevention of PTC, which has a good prognosis if detected early and treated appropriately [5, 6]. In addition, family history studies have suggested that the incidence of thyroid cancer may have a hereditary predisposition, with the reported relative risk estimates of 3 - to 4 -fold or higher $[7,8]$ when examining familial PTC occurrence. Some studies reported the close association between some gene variant and risk of PTC, suggesting that the genetic polymorphism may be used as a molecular marker to screen subjects at high risk [9-11] However, the ideal genetic marker for PTC incidence is still undetermined [12].

Osteopontin (OPN) is a matricellular protein that participates in a wide range of physiological and pathologic processes, including tumorigenesis and metastasis [13-16]. Recent studies showed that OPN is involved in the tumorigenesis of breast cancer [17-19], hepatic carcinoma [20], gastric cancer [21]. The role of OPN in thyroid cancer received much attention in recent years. In vitro studies revealed that the OPN plays a pivotal role in the expression of the mitogenic and invasive phenotype of RET/PTC-transformed thyroid cells [22]. Nearly all normal thyroid samples were negative for OPN; however, thyroid adenomas were OPN positive [23]. Clinically, OPN is over-expressed in human papillary thyroid carcinomas and enhances thyroid carcinoma cell invasiveness. The prevalence and intensity of OPN staining were significantly correlated with the presence of lymph node metastases and tumor size [24].

The expression of OPN was significantly influenced by its genetic polymorphisms of the promoter [25]. Several polymorphisms in the human OPN encoding gene have been identified in different populations, of which the $-156 \mathrm{GG}>\mathrm{G}$ genotype and $-443 \mathrm{~T}>\mathrm{C}$ polymorphisms were the most studied. Genetic polymorphisms in the OPN promoter also increases the risk of distance metastasis and death in Chinese patients with gastric cancer [26]. OPN gene polymorphisms are associated with susceptibility and clinicopatholigical characteristics of cervical cancer in a Chinese cohort [27]. OPN promoter polymorphisms at locus -443 significantly affect the metastasis and prognosis of human hepatocellular carcinoma [28]. However, no study regarding the role of OPN in PTC has been reported.

Based on the important significance of OPN in thyroid cancer risk, we postulated that the polymorphism of OPN gene might be associated with the risk and the clinical features of PTC. Thus, we performed current case-controls study to testify the hypothesis.

\section{Materials and Methods}

\section{Patients and controls}

PTC patients involved with this study were enrolled at our hospital between July 2006 and December 2011. PTC was confirmed by pathologic examination. Specimens determined to be benign tumors, follicular variants, and diffuse sclerosing were excluded. Eventually, 363 PTC patients were selected to participate. A total of 413 healthy control subjects were enrolled from a general health check-up program without clinical evidence of cancers, thyroid diseases, or any other chronic or severe conditions. This study was approved by the ethics review board of the Medical Research Institute of our hospital. Written informed consent was obtained from each subject prior to study entry.

\section{OPN gene polymorphisms}

DNA was extracted from peripheral whole blood using a Qiagen DNA Isolation Kit (Qiagen, Valencia, CA, USA). Three single nucleotide polymorphisms on the promoter region of OPN gene, including $-66 \mathrm{~T} / \mathrm{G}$ (rs28357094), -156G/GG (rs17524488), and -443C/T (rs11730582), were determined using TaqMan 5' allelic discrimination assay. It was performed using a commercially available kit Assays-on-DemandTM SNP genotyping products (Applied Biosystems, Foster City, CA). SNP amplification assays were used according to the manufacturer's instructions. In short, $10 \mathrm{ng}$ of sample DNA in $25 \mu \mathrm{L}$ of reaction solution containing $12.5 \mu \mathrm{L}$ of the $2 \times$ TaqMan ${ }^{\circledR}$ Universal PCR Mix (Applied Biosystems), and $1.25 \mu \mathrm{l}$ of pre-developed assay 


\begin{tabular}{|c|c|c|}
\hline Cellular Physiology & Cell Physiol Biochem 2013;32:171-179 & \\
\hline and Biochemistry & 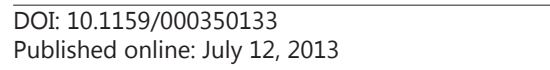 & $\begin{array}{l}\text { O } 2013 \mathrm{~S} \text {. Karger AG, Basel } \\
\text { www.karger.com/cpb }\end{array}$ \\
\hline
\end{tabular}

Table 1. shows the association between the CFTR SNPs and the clinical characteristics of PTC

\begin{tabular}{|c|c|c|c|}
\hline Characteristics & $\operatorname{PTC}(n=363)$ & Controls $(n=413)$ & $P$ \\
\hline e (years) & $38.6 \pm 2.1$ & $38.4 \pm 4.3$ & 0.254 \\
\hline \multicolumn{4}{|l|}{ Gender } \\
\hline Male & 143 & 204 & \multirow[t]{2}{*}{0.025} \\
\hline Female & 220 & 209 & \\
\hline \multicolumn{4}{|l|}{ Smoke status } \\
\hline Non-smokers & 271 & 126 & \multirow[t]{2}{*}{0.225} \\
\hline Smoker & 92 & 287 & \\
\hline \multicolumn{4}{|l|}{ Radiation exposure history } \\
\hline Yes & 51 & 2 & \multirow[t]{2}{*}{$<0.001$} \\
\hline No & 312 & 411 & \\
\hline \multicolumn{4}{|l|}{ Cancer size (n) } \\
\hline$<1 \mathrm{~cm}$ & 289 & & \\
\hline$>1 \mathrm{~cm}$ & 74 & & \\
\hline \multicolumn{4}{|l|}{ Number of tumors (n) } \\
\hline Unifocality & 211 & & \\
\hline Multifocality & 152 & & \\
\hline \multicolumn{4}{|l|}{ Location of cancer $(n)$} \\
\hline One lobe & 195 & & \\
\hline Both lobes & 168 & & \\
\hline \multicolumn{4}{|l|}{ Extra thyroidal invasion (n) } \\
\hline Absent & 188 & & \\
\hline Present & 175 & & \\
\hline \multicolumn{4}{|l|}{ Cervical lymph node metastasis ( $\mathrm{n}$ ) } \\
\hline Absent & 293 & & \\
\hline Present & 70 & & \\
\hline \multicolumn{4}{|l|}{ Angiolymphatic invasion (n) } \\
\hline Absent & 300 & & \\
\hline Present & 63 & & \\
\hline \multicolumn{4}{|l|}{ Distant metastases } \\
\hline Absent & 348 & & \\
\hline Present & 15 & & \\
\hline \multicolumn{4}{|l|}{ Extent of surgery } \\
\hline One side total+ contralateral resection & 261 & & \\
\hline Two sides total resection & 102 & & \\
\hline \multicolumn{4}{|l|}{ Treatment } \\
\hline Radio-iodine + surgery & 66 & & \\
\hline Surgery & 297 & & \\
\hline
\end{tabular}

reagent from the SNP genotyping product containing two primers and two MCB-Taqman probes. Reaction conditions consisted of pre incubation at $50^{\circ} \mathrm{C}$ for $2 \mathrm{~min}$, at $95^{\circ} \mathrm{C}$ for $10 \mathrm{~min}$, followed by 40 cycles of 95 ${ }^{\circ} \mathrm{C}$ for $15 \mathrm{~s}$ and $60^{\circ} \mathrm{C}$ for $1 \mathrm{~min}$. Amplifications were performed in an ABI Prism ${ }^{\circledR} 7500$ Sequence Detection System (Applied Biosystems). To re-confirm the results of genotypes, we randomly selected 25 patients and 25 controls ( $10 \%$ of the study subjects) for re-genotyping by direct sequencing; the results were $100 \%$ identical.

\section{Immunohistochemistry}

Formalin-fixed and paraffin-embedded 4- to 5- $\mu$ m-thick tumor sections were deparaffinized, placed in a solution of absolute methanol and $0.3 \%$ hydrogen peroxide for $30 \mathrm{~min}$, and treated with blocking serum for $20 \mathrm{~min}$. The slides were incubated overnight with anti-OPN monoclonal antibodies, with biotinylated anti-IgG, and finally with premixed avidin-biotin complex (Vector Laboratories, Inc., CA). The immune reaction was revealed with $0.06 \mathrm{mmol} / \mathrm{liter}$ diaminobenzidine (DAB-Dako, DakoCytomation, Carpinteria, $\mathrm{CA}$ ) and $2 \mathrm{mmol} / \mathrm{liter}$ hydrogen peroxide. The OPN immunostaining was mostly localized in the cytoplasm. Considering the percentage of OPN immune-positive tumor cells, a score of 1 was given when $\leq 10 \%$ of cells were positive; 2 when $10-50 \%$ of cells were positive and 3 when $\geq 50 \%$ of cells were positive. Signal intensity 
Table 2. The genotype distributions and allele frequencies of OPN polymorphisms in PTC and control subjects

\begin{tabular}{|c|c|c|c|c|c|c|c|c|c|}
\hline \multirow[t]{2}{*}{ OPN genotype } & & \multicolumn{2}{|l|}{ PTC } & \multicolumn{2}{|l|}{ Control } & \multirow{2}{*}{$\begin{array}{c}\text { adjusted } \\
\text { OR }\end{array}$} & \multicolumn{2}{|c|}{$95 \% \mathrm{CI}$} & \multirow{2}{*}{$\begin{array}{c}\text { adjusted } \\
\text { P }\end{array}$} \\
\hline & & $\mathrm{N}$ & $\%$ & $\mathrm{~N}$ & $\%$ & & & & \\
\hline \multirow[t]{5}{*}{$-156 / \mathrm{G} / \mathrm{GG}$} & GG & 104 & $25 \%$ & 100 & $21 \%$ & 1.000 & & & \\
\hline & GGG & 187 & $44 \%$ & 219 & $46 \%$ & 0.821 & 0.436 & 1.167 & 0.253 \\
\hline & GGGG & 72 & $17 \%$ & 94 & $20 \%$ & 0.736 & 0.478 & 1.143 & 0.147 \\
\hline & G & 395 & $47 \%$ & 419 & $44 \%$ & 1.000 & & & \\
\hline & GG & 446 & $53 \%$ & 532 & $56 \%$ & 0.889 & 0.712 & 1.134 & 0.221 \\
\hline \multirow[t]{5}{*}{$-66 \mathrm{~T} / \mathrm{G}$} & $\mathrm{TT}$ & 99 & $25 \%$ & 114 & $25 \%$ & 1.000 & & & \\
\hline & TG & 167 & $42 \%$ & 191 & $42 \%$ & 1.007 & 0.787 & 1.465 & 0.736 \\
\hline & GG & 97 & $24 \%$ & 108 & $24 \%$ & 1.034 & 0.724 & 1.753 & 0.887 \\
\hline & $\mathrm{T}$ & 365 & $46 \%$ & 419 & $46 \%$ & 1.000 & & & \\
\hline & G & 431 & $54 \%$ & 490 & $54 \%$ & 1.010 & 0.898 & 1.276 & 0.853 \\
\hline \multirow[t]{5}{*}{$-443 \mathrm{C} / \mathrm{T}$} & $\mathrm{TT}$ & 73 & $20 \%$ & 164 & $40 \%$ & 1.000 & & & \\
\hline & $\mathrm{CT}$ & 171 & $47 \%$ & 187 & $45 \%$ & 1.854 & 0.955 & 2.901 & 0.054 \\
\hline & CC & 119 & $33 \%$ & 62 & $15 \%$ & 4.312 & 2.747 & 6.987 & $<0.001$ \\
\hline & $\mathrm{T}$ & 317 & $44 \%$ & 515 & $62 \%$ & 1.000 & & & \\
\hline & $\mathrm{C}$ & 409 & $56 \%$ & 311 & $38 \%$ & 2.137 & 1.675 & 2.456 & 0.031 \\
\hline
\end{tabular}

was scored as negative (0), weak (1), moderate (2) and strong (3). Both scores were multiplied and the resulting score was used to categorize OPN expression as low (0-6) and high ( $>6)$ expressions [29].

\section{Statistical Analyses}

$\chi 2$ tests were used to compare genotype frequency and demographic distributions between cases and controls. Multiple logistic regression analyses were used to evaluate if each SNP was independently associated with PTC when adjusted for the potential confounding effects of important clinical variables. The odds ratios (OR) and 95\% confidence intervals (CIs) were calculated. All analyses were performed by using SPSS software (Statistical Package for the Social Sciences, version 16.0, SPSS Inc, Chicago, IL, USA).
Table 3. OPN expression status between PTC and normal tissues

\begin{tabular}{lcccc}
\hline & PTC & Control & P \\
\hline High OPN expression & 68 & 0 & $<0.001$ \\
Low OPN expression & 32 & 12 & \\
\hline
\end{tabular}

Table 4. The OPN genotype and OPN expression in PTC patients

\begin{tabular}{ccccccc}
\hline & & High 0PN & & Low 0PN & & P \\
\hline-443 C $>$ T & TT & 14 & $21 \%$ & 13 & $41 \%$ & $<0.001$ \\
& CT & 26 & $38 \%$ & 15 & $47 \%$ & \\
CC & 28 & $41 \%$ & 4 & $13 \%$ & \\
\hline
\end{tabular}

\section{Results}

The clinical characteristics of PTC cases and controls are listed in Table 1. The age and smoking status were similar between PTC and controls. The age and smoking status were similar between two groups. However, females and those with radiation exposure history were more numerous in the PTC group than in the control group $(\mathrm{P}=0.025$ and $\mathrm{P}>0.001$, respectively).

Table 2 describes the genotype distributions and allele frequencies of OPN poly-morphisms in PTC and control subjects. The genotype frequencies for all polymorphisms did not differ significantly from those expected under Hardy-Weinberg equilibrium (both $P>0.05$ ). The genotype frequencies and allele frequencies at OPN $-156 \mathrm{G}>\mathrm{GG}$ and -66 $\mathrm{T}>\mathrm{G}$ were similar in PTC and control subjects. In contrast, the genotype of $-443 \mathrm{C}>\mathrm{T}$ was significantly different between two groups. The PTC patients had significantly higher rates of CC genotypes than controls ( $33 \%$ vs.15\%, $\mathrm{P}<0.001$ ). Accordingly, the $-443 \mathrm{C}$ allele frequencies were higher in PTC patients than controls (56\% vs. 38\%, P=0.031). In order determine the association of OPN gene polymorphism with PTC risk, we performed the multivariate 


\begin{tabular}{|c|c|c|}
\hline Cellular Physiology & Cell Physiol Biochem 2013;32:171-179 & \\
\hline and Biochemistry & 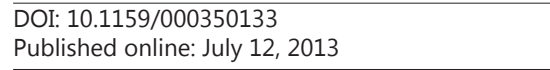 & $\begin{array}{l}\text { O) } 2013 \text { S. Karger AG, Basel } \\
\text { www.karger.com/cpb }\end{array}$ \\
\hline
\end{tabular}

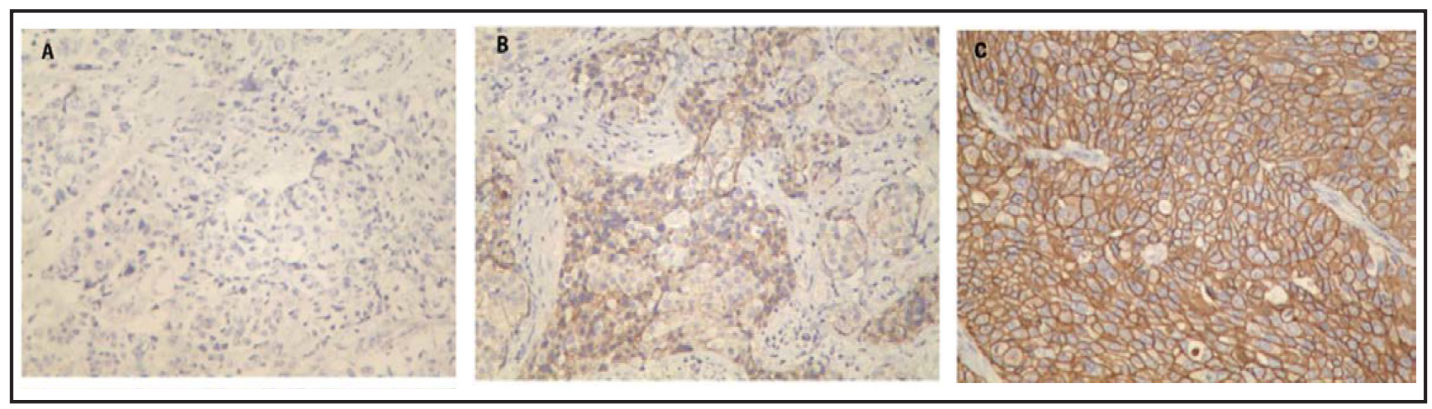

Fig. 1. A: No OPN expression in the non-tumor thyroid tissue samples from a patients with thyroiditis. B: Low OPN expression in PTC tumor tissues from a PTC patient with -443 TT genotype. C: High OPN expression in PTC tumor tissues from a PTC patient with -443 TT genotype.

logistic regression analysis with adjustment with age, sex and smoking status, family history, and radiation exposure history. Our data showed a significantly increased risk for PTC for the -443CC genotype compared with the -443TT genotype (adjusted OR $=4.312,95 \% \mathrm{CI}: 2.747$ -6.987 , adjusted $\mathrm{P}<0.001$ ) after adjustment.

The OPN expressions in PTC tumor samples were determined by immuhistological staining. We collected 100 samples from surgical treatment or fine needle biopsy and obtained non-tumor thyroid tissue samples from 12 patients that underwent thyroid resection due to thyroiditis. We found no OPN expression in all the non-tumor thyroid tissue samples and observed that OPN was highly expressed in 68 of 100 samples from PTC tumor tissue. A significant difference of OPN expression status between PTC and normal tissues was noted $(\mathrm{P}<0.001$, Table 3$)$. The typical OPN expressions are showed in Figure 1.

We next analyzed the OPN genotype and its protein levels in PTC patients. We observed that the high OPN expression was more
Table 5. The correlation between the OPN polymorphisms and PTC clinical features

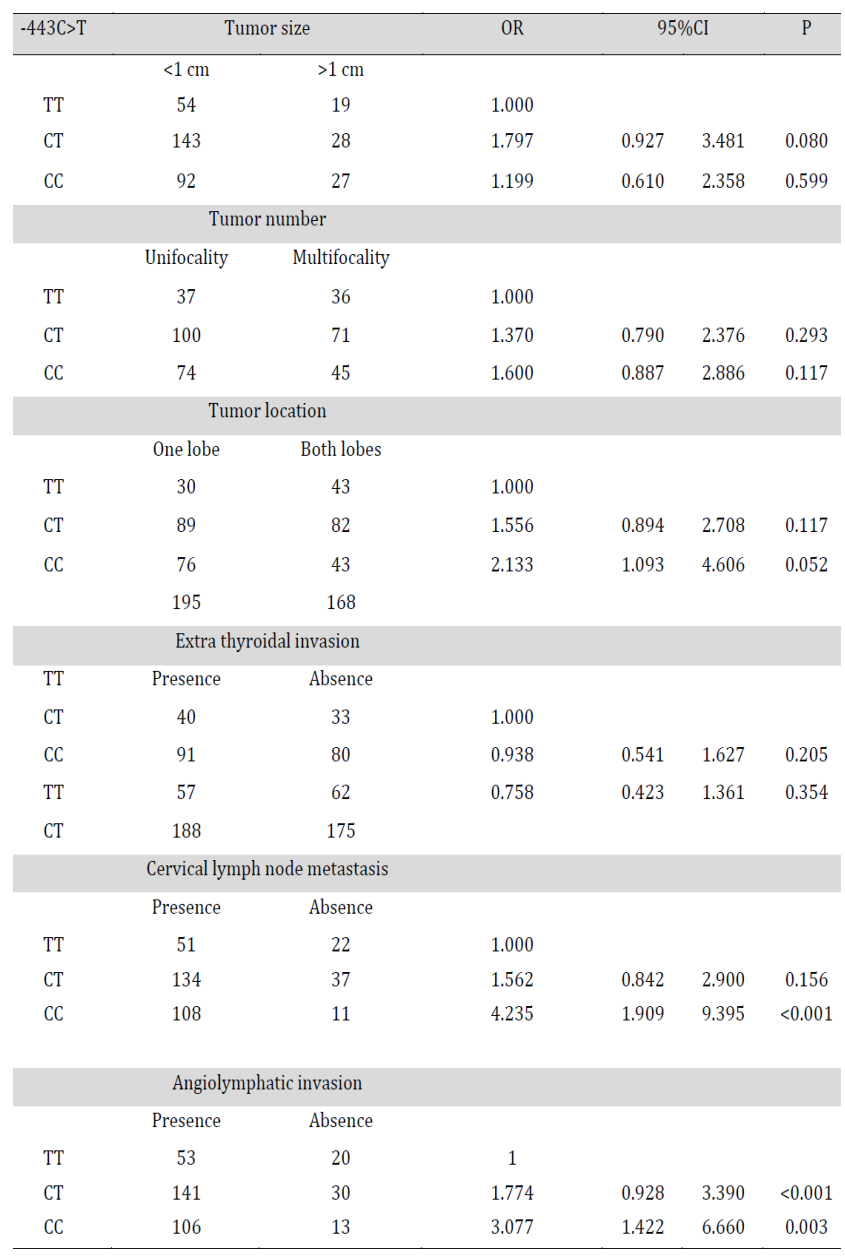

frequent in samples from -443CC carriers than TT carriers (41\% vs. $21 \%, \mathrm{P}<0.001$, Table 4).

We next analyzed the correlation between the OPN polymorphisms and the clinical features. We found that the $-443 \mathrm{C}>\mathrm{T}$ was not associated with tumor size, tumor number, or tumor location, but was significantly related to the cervical lymph node metastasis and angiolymphatic invasion. -443CC carriage was significantly associated with higher risk for cervical lymph node metastasis and angiolymphatic invasion compared with -443 TT carriage (Adjusted $\mathrm{OR}=4.235, \mathrm{P}<0.001$ and $\mathrm{OR}=1.422, \mathrm{P}=0.003$, respectively, Table 5). 
The correlation between the tumor tissue OPN expression and PTC clinical feature is showed in Table 6. The OPN high expression was related to the cervical lymph node metastasis and angiolymphatic invasion as well.

\section{Discussion}

In the present study, we observed that the PTC patients had significantly higher rates of -443CC genotypes than controls $(\mathrm{P}<0.001)$. The multivariate logistic regression analysis showed a significantly increased risk for PTC for the -443CC genotype compared with the -443TT genotype (adjusted $\mathrm{OR}=4.312, \quad 95 \% \mathrm{CI}: 2.747-6.987$, adjusted $\mathrm{P}<0.001$ ). OPN was not expressed in normal thyroid tissues but was highly expressed in tumor sample from PTC patients. Also, we found that the high OPN expression were significantly more prevalent in $-443 \mathrm{C}>\mathrm{T}$ polymorphisms and the tumor tissue OPN expression were closely associated with the cervical lymph node metastasis and angiolymphatic invasion of PTC. This study provides evidence to support the connection between the OPN genetic polymorphism and tissue expression with risk as well as the invasiveness of PTC.

Previous research has elucidated that OPN is up-regulated in a variety of cancers, such as breast, gastric, and colorectal cancers as well as in some highly metastatic cancer cell lines $[12,13]$. High OPN levels in plasma and tissue were associated with shorten survival of patients with advanced cervical cancer [30]. Low OPN levels were significantly associated with a favorable prognosis with advanced non-small cell lung cancer [31], laryngeal and hypopharyngeal carcinomas[32], hepatocellular carcinoma[33], colorectal cancer[34, 35], upper urinary tract urothelial carcinoma [36], oral squamous cell carcinoma [37, 38], and endometrial cancer $[39,40]$. OPN is classified as a Th1 cytokine/chemokine. One previous study reported the expression of Th1 chemokine (C-X-C motif) ligand 10 in anaplastic thyroid cancer, but not in the normal thyroid follicular cells [41]. In agreement with previous studies, we also found that high OPN expression in thyroid tissue of PTC patients while non-tumor thyroid tissue had no OPN expression. More interestingly, we found that the OPN expression levels were associated with the invasiveness of PTC. In addition, high OPN expression conferred higher rate of cervical lymph node metastasis and angiolymphatic invasion of PTC. Recent studies have reported that OPN plays important roles in cellular adhesion and migration, tissue repair, signal transduction and in the invasion and metastasis of several cancers at the molecular level $[42,43]$, suggesting that OPN expression could be used as a biomarker for PTC invasiveness.

The OPN encoding genes mapped on human chromosome 4q21-q25 and polymorphisms in the OPN gene promoter may affect its transcriptional activity [44]. More than fifty single nucleotide polymorphisms have been identified in the human OPN encoding gene in different populations, of which three single nucleotide polymorphisms on the promoter region of OPN gene, namely, $-66 \mathrm{~T}>\mathrm{G}$ ( $\mathrm{rs} 28357094),-156 \mathrm{G}>\mathrm{GG}$ (rs17524488), and $-443 \mathrm{C}>\mathrm{T}$ (rs11730582), were the most studied [44]. A previous study explored the possible role of $-443 \mathrm{~T}>\mathrm{C}$ for OPN expression in melanoma cells. The authors found that the -443CC genotype had higher levels 
of OPN mRNA compared with other allelic variants and $-443 \mathrm{C}>\mathrm{T}$ variants might influence the OPN mRNA levels via binding of c-Myb transcription factor [45]. In oral squamous cell carcinoma (OSCC) patients, the $-443 \mathrm{~T} / \mathrm{T}$ genotype was found to be more prevalent in OSCC patients [25]. Our data showed that the only genotype of $-443 \mathrm{C}>\mathrm{T}$ were significantly related to the PTC risk, rather than the other two. More importantly, we observed that the high OPN expression was more frequent in samples from -443CC carriers than TT carriers. This is consistent with the result of a previous study, which explored the promoter activity of the -443 $\mathrm{C}>\mathrm{T}$ polymorphism using a dual luciferase reporter assay. The author found that significantly higher luciferase activities were observed in the pGL3-C construct compared to the pGL3-T construct [26].

As far as PTC clinical features are concerned, -443CC carriage was significantly associated with higher risk for cervical lymph node metastasis and angiolymphatic invasion compared with -443 TT carriage. These data imply that the $-443 \mathrm{C}>\mathrm{T}$ polymorphism might affect the PTC risk and invasiveness by influencing the OPN expression in tumor tissues. The $-443 \mathrm{CC}$ of $-443 \mathrm{C}>\mathrm{T}$ polymorphisms was significantly associated with the angiolymphatic invasion and extra thyroidal invasion. This study suggests the $-443 \mathrm{C}>\mathrm{T}$ polymorphisms and tissue OPN expression may be used as molecular marker for the PTC incidence and invasion, including cervical lymph node metastasis and angiolymphatic invasion.

Most thyroid cancers have an excellent prognosis; both papillary and follicular thyroid cancers have about $85 \%$ to $90 \%$ cure rates, if detected early and treated appropriately. A deeper understanding of the genetic expression of OPN could lead to better treatment and prevention.

Some limitation in this study should be addressed. Firstly, this is a single center based study, which included Chinese patients from northern China, specifically Liaoning, Jilin and Heilongjiang provinces. The associations of OPN gene polymorphism with PTC need to be duplicated in other ethnic populations. Secondly, even though we found the association of OPN gene polymorphism and expression with PTC invasiveness, we did not have a follow-up study to investigate their prognostic role in PTC patients.

\section{Acknowledgements}

We thank Mrs Elisa Miguel from University of Mississippi Medical Center for her help in language revision. This work was supported by The Youth Foundation of the Affiliated Hospital of Dalian Medical University.

\section{References}

1 Al-Zahrani AS, Ravichandran K: Epidemiology of thyroid cancer: a review with special reference to Gulf Cooperation Council (GCC) states. Gulf J Oncolog 2007;2:17-28.

2 Colonna M, Bossard N, Guizard AV, Remontet L, Grosclaude P: Descriptive epidemiology of thyroid cancer in France: incidence, mortality and survival. Ann Endocrinol (Paris) 2010;71:95-101.

3 Nagataki S, Nystrom E: Epidemiology and primary prevention of thyroid cancer. Thyroid 2002;12:889-896.

4 Akslen L: Thyroid-cancer - some aspects of epidemiology and etiologic factors, pathological features and tumor biology. Int J Oncol 1994;4:931-942.

5 Sipos JA, Mazzaferri EL: Thyroid cancer epidemiology and prognostic variables. Clin Oncol (R Coll Radiol) 2010;22:395-404.

6 Miccoli P, Miccoli M, Antonelli A, Minuto MN: Clinicopathologic and molecular disease prognostication for papillary thyroid cancer. Expert Rev Anticancer Ther 2009;9:1261-1275.

7 Agate L, Lorusso L, Elisei R: New and old knowledge on differentiated thyroid cancer epidemiology and risk factors. J Endocrinol Invest 2012;35:3-9. 


\section{Cellular Physiology $\quad$ Cell Physiol Biochem 2013;32:171-179 and Biochemistry \begin{tabular}{l|l} 
DOI: 10.1159/000350133 & $\begin{array}{l}\text { C) 2013 S. Karger AG, Basel } \\
\text { www.karger.com/cpb }\end{array}$ \\
\hline
\end{tabular} \\ $\mathrm{Mu} /$ Wang/Cai/Ji: OPN and PTC}

8 Fincham SM, Ugnat AM, Hill GB, Kreiger N, Mao Y: Is occupation a risk factor for thyroid cancer? Canadian Cancer Registries Epidemiology Research Group. J Occup Environ Med 2000;42:318-322.

-9 Kitahara CM, Neta G, Pfeiffer RM, Kwon D, Xu L, Freedman ND, Hutchinson AA, Chanock SJ, Sturgis EM, Sigurdson AJ, Brenner AV: Common obesity-related genetic variants and papillary thyroid cancer risk. Cancer Epidemiol Biomarkers Prev 2012;21:2268-2271.

10 Hucz J, Kowalska M, Jarzab M, Wiench M: Gene expression of metalloproteinase 11, claudin 1 and selected adhesion related genes in papillary thyroid cancer. Endokrynol Pol 2006;57:S18-25.

11 Aschebrook-Kilfoy B, Neta G, Brenner AV, Hutchinson A, Pfeiffer RM, Sturgis EM, Xu L, Wheeler W, Doody MM, Chanock SJ, Sigurdson AJ: Common genetic variants in metabolism and detoxification pathways and the risk of papillary thyroid cancer. Endocr Relat Cancer 2012;19:333-344.

12 Romei C, Fugazzola L, Puxeddu E, Frasca F, Viola D, Muzza M, Moretti S, Nicolosi ML, Giani C, Cirello V, Avenia N, Rossi S, Vitti P, Pinchera A, Elisei R: Modifications in the papillary thyroid cancer gene profile over the last 15 years. J Clin Endocrinol Metab 2012;97:E1758-1765.

13 Giachelli CM, Steitz S: Osteopontin: a versatile regulator of inflammation and biomineralization. Matrix Biol 2000;19:615-622.

14 Heilmann K, Hoffmann U, Witte E, Loddenkemper C, Sina C, Schreiber S, Hayford C, Holzlöhner P, Wolk K, Tchatchou E, Moos V, Zeitz M, Sabat R, Günthert U, Wittig BM: Osteopontin as two-sided mediator of intestinal inflammation. J Cell Mol Med 2009;13:1162-1174.

15 Wolak T, Kim H, Ren Y, Kim J, Vaziri ND, Nicholas SB: Osteopontin modulates angiotensin II-induced inflammation, oxidative stress, and fibrosis of the kidney. Kidney Int 2009;76:32-43.

-16 Zhivkova-Galunska M, Adwan H, Eyol E, Kleeff J, Kolb A, Bergmann F, Berger MR: Osteopontin but not osteonectin favors the metastatic growth of pancreatic cancer cell lines. Cancer Biol Ther 2010;10:54-64.

17 Mirza M, Shaughnessy E, Hurley JK, Vanpatten KA, Pestano GA, He B, Weber GF: Osteopontin-c is a selective marker of breast cancer. Int J Cancer 2008;122:889-897.

18 Wu Y, Jiang W, Wang Y, Wu J, Saiyin H, Qiao X, Mei X, Guo B, Fang X, Zhang L, Lou H, Wu C, Qiao S: Breast cancer metastasis suppressor 1 regulates hepatocellular carcinoma cell apoptosis via suppressing osteopontin expression. PLoS One 2012;7:e42976.

19 Beausoleil MS, Schulze EB, Goodale D, Postenka CO, Allan AL: Deletion of the thrombin cleavage domain of osteopontin mediates breast cancer cell adhesion, proteolytic activity, tumorgenicity, and metastasis. BMC Cancer 2011;11:25.

20 Wu GL, Zhang L, Li TY, Chen J, Yu GY, Li JP: Short-term effect of combined therapy with Jinlong Capsule and transcatheter arterial chemoembolization on patients with primary hepatic carcinoma and its influence on serum osteopontin expression. Chin J Integr Med 2010;16:109-113.

-21 Imano M, Satou T, Itoh T, Sakai K, Ishimaru E, Yasuda A, Peng YF, Shinkai M, Akai F, Yasuda T, Imamoto H, Okuno K, Ito H, Shiozaki H, Ohyanagi H: Immunohistochemical expression of osteopontin in gastric cancer. J Gastrointest Surg 2009;13:1577-1582.

-22 Castellone MD, Celetti A, Guarino V, Cirafici AM, Basolo F, Giannini R, Medico E, Kruhoffer M, Orntoft TF, Curcio F, Fusco A, Melillo RM, Santoro M: Autocrine stimulation by osteopontin plays a pivotal role in the expression of the mitogenic and invasive phenotype of RET/PTC-transformed thyroid cells. Oncogene 2004;23:2188-2196.

-23 Briese J, Cheng S, Ezzat S, Liu W, Winer D, Wagener C, Bamberger AM, Asa SL: Osteopontin (OPN) expression in thyroid carcinoma. Anticancer Res 2010;30:1681-1688.

-24 Guarino V, Faviana P, Salvatore G, Castellone MD, Cirafici AM, De Falco V, Celetti A, Giannini R, Basolo F, Melillo RM, Santoro M: Osteopontin is overexpressed in human papillary thyroid carcinomas and enhances thyroid carcinoma cell invasiveness. J Clin Endocrinol Metab 2005;90:5270-5278.

25 Chiu YW, Tu HF, Wang IK, Wu CH, Chang KW, Liu TY, Kao SY: The implication of osteopontin (OPN) expression and genetic polymorphisms of OPN promoter in oral carcinogenesis. Oral Oncol 2010;46:302306.

26 Zhao F, Chen X, Meng T, Hao B, Zhang Z, Zhang G: Genetic polymorphisms in the osteopontin promoter increases the risk of distance metastasis and death in Chinese patients with gastric cancer. BMC Cancer 2012;12:477.

-27 Xu Q, Yuan B, Xue F, Zhang L, Li J, Guo H, Yue T: OPN gene polymorphisms are associated with susceptibility and clinicopatholigical characteristics of cervical cancer in a Chinese cohort. Cancer Biomark 2011;10:233239. 


\begin{tabular}{|c|c|c|}
\hline Cellular Physiology & Cell Physiol Biochem 2013;32:171-179 & \\
\hline and Biochemistry & 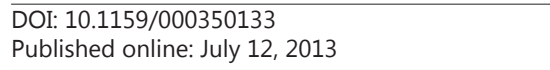 & $\begin{array}{l}\text { O } 2013 \text { S. Karger AG, Basel } \\
\text { www.karger.com/cpb }\end{array}$ \\
\hline
\end{tabular}

28 Dong QZ, Zhang XF, Zhao Y, Jia HL, Zhou HJ, Dai C, Sun HJ, Qin Y, Zhang WD, Ren N, Ye QH, Qin LX: Osteopontin promoter polymorphisms at locus -443 significantly affect the metastasis and prognosis of human hepatocellular carcinoma. Hepatology 2013;57:1024-1034.

-29 Soini Y, Kahlos K, Puhakka A, Lakari E, Säily M, Pääkkö P, Kinnula V: Expression of inducible nitric oxide synthase in healthy pleura and in malignant mesothelioma. Br J Cancer 2000;83:880-886.

-30 Cho H, Hong SW, Oh YJ, Kim MA, Kang ES, Lee JM, Kim SW, Kim SH, Kim JH, Kim YT, Lee K: Clinical significance of osteopontin expression in cervical cancer. J Cancer Res Clin Oncol 2008;134:909-917.

-31 Isa S, Kawaguchi T, Teramukai S, Minato K, Ohsaki Y, Shibata K, Yonei T, Hayashibara K, Fukushima M, Kawahara M, Furuse K, Mack PC: Serum osteopontin levels are highly prognostic for survival in advanced non-small cell lung cancer: results from JMTO LC 0004. J Thorac Oncol 2009;4:1104-1110.

32 Li Y, Li L, Wang JT, Kan X, Lu JG: Elevated content of osteopontin in plasma and tumor tissues of patients with laryngeal and hypopharyngeal carcinoma associated with metastasis and prognosis. Med Oncol 2012;29:1429-1434.

33 Sieghart W, Wang X, Schmid K, Pinter M, König F, Bodingbauer M, Wrba F, Rasoul-Rockenschaub S, Peck-Radosavljevic M: Osteopontin expression predicts overall survival after liver transplantation for hepatocellular carcinoma in patients beyond the Milan criteria. J Hepatol 2011;54:89-97.

34 Ding L, Zheng S: [Expression and clinical significance of osteopontin in colorectal cancer and liver metastatic tissues]. Zhonghua Wai Ke Za Zhi 2002;40:773-775.

-35 Ding L, Zheng S, Cao J: [Expression of osteopontin mRNA and its protein in colorectal cancer and liver metastatic tissues]. Zhonghua Yi Xue Za Zhi 2002;82:970-973.

-36 Ke HL, Chang LL, Yang SF, Lin HH, Li CC, Wu DC, Wu WJ: Osteopontin overexpression predicts poor prognosis of upper urinary tract urothelial carcinoma. Urol Oncol 2011;29:703-709.

-37 Matsuzaki H, Shima K, Muramatsu T, Ro Y, Hashimoto S, Shibahara T, Shimono M: Osteopontin as biomarker in early invasion by squamous cell carcinoma in tongue. J Oral Pathol Med 2007;36:30-34.

-38 Shimada Y, Watanabe G, Kawamura J, Soma T, Okabe M, Ito T, Inoue H, Kondo M, Mori Y, Tanaka E, Imamura M: Clinical significance of osteopontin in esophageal squamous cell carcinoma: comparison with common tumor markers. Oncology 2005;68:285-292.

39 Cho H, Kang ES, Kim YT, Kim JH: Diagnostic and prognostic impact of osteopontin expression in endometrial cancer. Cancer Invest 2009;27:313-323.

-40 Hashiguchi Y, Tsuda H, Bandera CA, Nishimura S, Inoue T, Kawamura N, Berkowitz RS, Mok SC: Comparison of osteopontin expression in endometrioid endometrial cancer and ovarian endometrioid cancer. Med Oncol 2006;23:205-212.

41 Antonelli A, Ferrari SM, Fallahi P, Piaggi S, Di Domenicantonio A, Galleri D, Santarpia L, Basolo F, Ferrannini E, Miccoli P: Variable modulation by cytokines and thiazolidinediones of the prototype Th1 chemokine CXCL10 in anaplastic thyroid cancer. Cytokine 2012;59:218-222.

42 Zhao XQ, Dong JH, Zhang WZ, Liu Z: Prognosis of ampullary cancer based on immunohistochemical type and expression of osteopontin. Diagn Pathol 2011;6:98.

43 Zhang R, Pan X, Huang Z, Weber GF, Zhang G: Osteopontin enhances the expression and activity of MMP-2 via the SDF-1/CXCR4 axis in hepatocellular carcinoma cell lines. PLoS One 2011;6:e23831.

44 Giacopelli F, Marciano R, Pistorio A, Catarsi P, Canini S, Karsenty G, Ravazzolo R: Polymorphisms in the osteopontin promoter affect its transcriptional activity. Physiol Genomics 2004;20:87-96.

45 Schultz J, Lorenz P, Ibrahim SM, Kundt G, Gross G, Kunz M: The functional -443T/C osteopontin promoter polymorphism influences osteopontin gene expression in melanoma cells via binding of c-Myb transcription factor. Mol Carcinog 2009;48:14-23. 